University of Nebraska - Lincoln

DigitalCommons@University of Nebraska - Lincoln

Agronomy \& Horticulture -- Faculty Publications

Agronomy and Horticulture Department

1969

\title{
Interrelationships Among Photosynthesis, Respiration, and Movement of Carbon in Developing Crops
}

\author{
Volkmar Stoy \\ Swedish Seed Association, Svalöf, Sweden
}

Follow this and additional works at: https://digitalcommons.unl.edu/agronomyfacpub

Part of the Plant Sciences Commons

Stoy, Volkmar, "Interrelationships Among Photosynthesis, Respiration, and Movement of Carbon in Developing Crops" (1969). Agronomy \& Horticulture -- Faculty Publications. 199.

https://digitalcommons.unl.edu/agronomyfacpub/199

This Article is brought to you for free and open access by the Agronomy and Horticulture Department at DigitalCommons@University of Nebraska - Lincoln. It has been accepted for inclusion in Agronomy \& Horticulture -Faculty Publications by an authorized administrator of DigitalCommons@University of Nebraska - Lincoln. 
Published in Physiological Aspects of Crop Yield: Proceedings of a symposium sponsored by the University of Nebraska, the American Society of Agronomy, and the Crop Science Society of America, and held at the University of Nebraska, Lincoln, Nebr., January 20-24, 1969. Edited by Jerry D. Eastin, F. A. Haskins, C. Y. Sullivan, C. H. M. Van Bavel, and Richard C. Dinauer (Madison, Wisconsin: American Society of Agronomy \& Crop Science Society of America, 1969). Copyright (C) 1969 American Society of Agronomy \& Crop Science Society of America. Used by permission. 


\title{
Interrelationships Among Photosynthesis, Respiration, and Movement of Carbon in Developing Crops
}

\author{
VOLKMAR STOY \\ Swedish Seed Association \\ Svalöf, Sweden
}

From the preceding lectures we have learned a great deal about how external conditions may influence various internal physiological processes within plants, and it therefore appears appropriate to consider briefly how these processes influence one another and also the manner in which they relate to yield. The main processes of interest in this connection are photosynthesis, respiration, and carbon assimilate translocation; but aspects of growth, development, mineral nutrition, etc., will also be considered when relevant.

\section{INTERDEPENDENCE OF PHOTOSYNTHESIS AND RESPIRATION}

\section{A. Photosynthesis and Respiration in Individual Plants}

According to the classical view, photosynthesis and respiration are two opposite processes, proceeding simultaneously and independently in all green tissues. Respiration has thus been believed to proceed at the same rate in light and in darkness, and as a consequence gross photosynthesis in illuminated plant parts has commonly been calculated by applying the formula:

gross photosynthesis $=$ net photosynthesis + dark respiration.

However, the possibility that a light-dependent respiration exists different in nature and magnitude from ordinary dark respiration, and thus counteracting photosynthesis at a varying rate has been, to quote Rabinowitch (1945) "... a nightmare oppressing all who are concerned 
Table 9-1-The magnitude of the Warburg effect in different plant species. The estimates refer to normal $\mathrm{O}_{2}$ concentration in the air $(20 \%)$, high light intensities, and temperatures between 20 and $25 \mathrm{C}$

\begin{tabular}{|c|c|c|c|}
\hline Specles & $\mathrm{CO}_{2}$ conc., & $\begin{array}{l}\text { \% inhibition of } \\
\text { photosynthesis }\end{array}$ & References \\
\hline Chlorella pyrenoidosa (alga) & 0.2 & 20 & Warburg $(1920)$ \\
\hline Chlorella pyrenoidosa (alga) & 0.03 & 0 & Fock \& Egle (1966) \\
\hline Triticum sp. (wheat) & 0.03 & 25 & McAlister \& Myers (1940) \\
\hline \multicolumn{4}{|l|}{ Solidago virgaurea } \\
\hline (European goldenrod) & 0.03 & 33 & Björkman (1967) \\
\hline \multicolumn{4}{|l|}{ Mimulus cardinalis } \\
\hline (Crims on monkeyflower) & 0.03 & 32 & Björkman (1967) \\
\hline Zea mays (corn) & 0.03 & 0 & Björkman (1967) \\
\hline Amaranthus edulis & 0.03 & 0 & Björkman (1967) \\
\hline
\end{tabular}

with the exact measurement of photosynthesis." Also to those dealing with problems of plant productivity, the question is of great interest and will therefore be briefly elucidated.

Warburg (1920) observed many years ago in Chlorella that the rate of apparent photosynthesis was considerably decreased when the concentration of oxygen in the surrounding medium was increased from 2 to $100 \%$. At an oxygen concentration corresponding to that in normal air, inhibition was about $20 \%$. The existence of the Warburg effect in higher plants was reported 20 years later by McAlister and Myers (1940), who observed the phenomenon in wheat leaves (Table 9-1).

Different explanations have been given for the Warburg effect (cf. Turner and Brittain, 1962), one of them being that it is caused by increased respiration. Since dark respiration is known to be practically independent of oxygen concentration within the range of 2 to $100 \% \mathrm{Oz}$, this presumptive respiration thus has to be light-dependent, and has consequently been termed photorespiration.

It is practically impossible-or at least extremely difficult-to make exact measurements of the rate of photorespiration under normal growth conditions since the simultaneously occurring photosynthesis interferes with and counteracts the respiratory gas exchange. For a long time, therefore, the existence of photorespiration was much ques tioned, but today the positive evidence is so overwhelming that there hardly can be any doubt about its reality (see e.g., Decker 1955, Tregunna, Krotkov, and Nelson 1961, 1964, 1966; Egle and Döhler 1963; Fock and Egle 1966; Moss 1966, 1968; Forrester, Krotkov, and Nelson 1966a,b; Holmgren and Jarvis 1967; Poskuta, Nelson, and Krotkov 1967; Poskuta 1968; Downton and Tregunna 1968a; Joliffe and Tregunna 1968; Fock, Schaub, and Hilgenberg 1969.

An important step towards a correct interpretation of the experimental results was the discovery of Hoch, Owens, and Kok (1963) (see also Ozbun, Volk, and Jackson, 1964; Tregunna et al., 1966; Forrester et al., 1966a,b; Holmgren and Jarvis, 1967) that dark respiration and photorespiration are quite different processes and that dark respiration is inhibited already at very weak light intensities. Moreover, the rate of photorespiration in normal air and at medium to high light intensities has in most cases been found to be one to two times that of dark respiration (Moss, 1966; Forrester et al., 1966a; Goldsworthy, 1966; see, 
however, Ozbun et al., 1964; Brix, 1968). On the other hand, in some species no photorespiration at all appears to exist (Tregunna et al., 1964; Forrester et al., 1966b; Björkman, 1967; Hesketh, 1967)(cf. Table 9-1). This observation has to be correlated with another phenomenon that had been reported already several years earlier.

If plants are placed in a closed assimilation chamber and subsequently illuminated, the $\mathrm{CO}_{z}$ content of the air in this chamber soon reaches an equilibrium value, the magnitude of which is dependent on light intensity, temperature, $\mathrm{O}_{2}$ concentration, etc. This value is called the compensation concentration (also designated $\Gamma$ ), and it has been shown by several workers (Meidner, 1962; Moss, 1962a) that $\Gamma$ may attain rather different values for different species. As a matter of fact, two distinct groups of plant species can be distinguished, one exhibiting a compensation concentration of about $5 \mathrm{ppm}$ and another one compensating at $50-100 \mathrm{ppm}$ of $\mathrm{CO}_{2}$ in the atmosphere. The first group comprises both a number of so-called tropical grasses (e.g., Zea, Sorghum, and Saccharum) and dicots, such as Amaranthus, whereas to the second group belong, amongst others, temperate grasses, such as Triticum Hordeum, Avena, Poa, Festuca (and also Oryza), as well as most of the investigated dicots (e.g., Glycine, Beta, Nicotiana, and Phaseolus).

The interesting thing is that all members of the low-compensating group appear not to be undergoing photorespiration whereas the highcompensating plants all seem to respire significantly when illuminated.

A biochemical mechanism to explain this phenomenon has been suggested by Zelitch $(1958,1959,1966)$. According to his theory, glycolic acid is formed during the course of photosynthesis, and from the oxidation of glycolic acid $\mathrm{CO}_{2}$ arises that is subsequently released in photorespiration, and thus causes the high compensation concentration. In low-compensating species the absence of $\mathrm{CO}_{2}$ evolution might be due either to a block in some step in the oxidation of glycolic acid (as proposed by Tregunna, 1966 and Zelitch, 1966; see, however, Downton and Tregunna, 1968a) or to the lack of sufficient amounts of glycolic acid. The latter possibility has been considered as less probable (Zelitch, 1966).

In a recent study by Moss (1968), it was reported, however, that the production and subsequent oxidation of glycolate is not sufficiently large to account for the lower net photosynthesis found in, e.g., tobacco (Nicotiana tabacum L.) as compared with maize (which does not photorespire). It may be necessary therefore to consider also other mechanisms and this has, in fact, been done by some authors (El-Sharkawy, Loomis, and Williams, 1967; Hesketh and Baker, 1967). These authors proposed that the difference between the two groups of species may be explained instead by assuming that certain species possess a much stronger ability to reassimilate the $\mathrm{CO}_{2}$ evolved than others and that the absence of photorespiration thus is only apparent. This interpretation has been rejected, however, by Downton and Tregunna (1968a).

One argument that has been raised to support the reassimilation hypothesis is founded on the observation that species showing low compensation concentration also possess certain characteristic anatomical features, such as a well-developed sheath of parenchymatous cells (rich in chloroplasts) around the vascular bundles and a particularly large, 
exposed cell surface per cell volume (Rhoades and Carvalho, 1944; ElSharkawy and Hesketh, 1965; Downton and Tregunna, 1968b). These features are thought to facilitate a rapid gas exchange and thus a strong reassimilation of $\mathrm{CO}_{2}$ released in photorespiration. Other factors favoring a rapid recycling of $\mathrm{CO}_{z}$ might be faster rates of the dark enzymatic reactions in the chloroplasts (E1-Sharkawy et al., 1967; Mansfield, 1968) or low cytoplasmatic resistance to $\mathrm{CO}_{2}$ diffusion from the site of respiration to the site of assimilation (E1-Sharkawy et al., 1967).

Another interesting difference between the high- and low-compensating plants has been revealed during the last few years. It has been reported by several groups (Kortschak, Hartt, and Burr, 1965; Hatch and Slack, 1966) that the biochemical path way of photosynthesis in sugarcane (Saccharum officinarum L.) is different from the ordinary Calvin pathway starting with the carboxylation of ribulose diphosphate. This new pathway, often called the $\mathrm{C}_{4}$-pathway, since a number of 4-carbon dicarboxylic acids form the primary product of the carboxylation, has later been found to be dominating in all those members of the lowcompensating group that have been investigated for it (Slack and Hatch, 1967; Hatch, Slack, and Johnson, 1967; see also Downton and Tregunna, 1968b). This correlation can hardly be a mere coincidence, and it would be most interesting to know more about the biochemical similarities and differences between these groups of plants.

The two groups of plants differ in still another very important respect: they do not show the same rates of net photosynthesis. Whereas the low-compensating plants in normal air and at optimal light and temperature conditions all photosynthesize at a rate of about $50-60 \mathrm{mg}$ $\mathrm{CO}_{\mathrm{s}} / \mathrm{dm}^{2} / \mathrm{h}$, the high-compensating plants rarely reach above $35 \mathrm{mg}$ $\mathrm{CO}_{2} / \mathrm{dm}^{2} / \mathrm{h}$ (El-Sharkawy and Hesketh, 1964, 1965; Moss, Musgrave, and Lemon, 1961; Hesketh and Moss, 1963; Murata and Iyama, 1963; Stoy, 1965). (Fig. 9-1). This difference could of course be attributed to the loss of carbon through photorespiration of the high-compensating

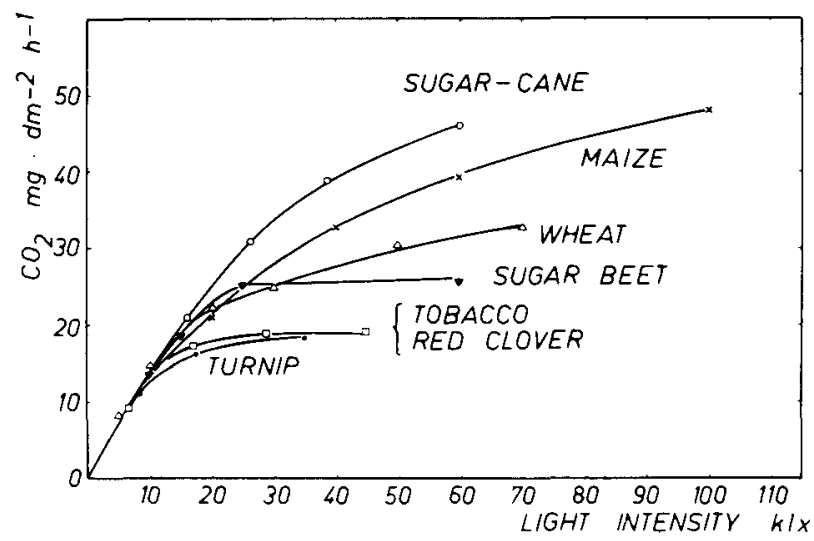

Fig. 9-1-Light response curves of photosynthesis for different crop plants. Attached leaves, $\mathrm{CO}_{2}$ concentration $=0.03 \mathrm{vol} . \%$, temperature $=20 \mathrm{C}$ (From Stoy, 1965). 
plants, but it could also be caused by a real difference in the rate of gross photosynthesis. The previously mentioned study by Moss (1968), according to which the estimated rates of photorespiration appear to be too small to account for the total difference in rates of net photosynthesis, lends support to this possibility.

\section{B. Photosynthetic Production and Respiratory Consumption} in Plant Communities

In a plant community photosynthetic production rises with increasing size of thefoliage per ground area (leaf area index, LAI). However, this rise does not go on indefinitely; but is limited by mutual shading of the leaves, whereby the mean photosynthetic production per unit leaf area (net assimilation rate, NAR) is decreased. It has been a matter of considerable disagreement whether an optimal LAI value exists at which the rate of total photosynthetic production (crop growth rate, $\mathrm{C}$, according to Watson, 1958) reaches its maximum value, or whether this maximum is approached asymptotically with increasing LAI.

Results from work of Davidson and Philip (1958), Watson (1958), Davidson and Donald (1958), and Black (1963) indicated the existence of a definite optimal LAI; but other investigations (Brougham, 1956; Watson, Thorne, and French, 1963; Wang and Wei, 1964; Stoy, 1965; Nichiporovich and Malof eyev, 1965; Ludwig, Saeki, and Evans, 1965; Williams, Loomis, and Epley, 1965; Shibles and Weber, 1965; Wilfong, Brown, and Blaser, 1967; King and Evans, 1967) did in general not confirm these conclusions.

The reason for this discrepancy may be sought in the different light interception of the various plant species used in the investigations, and also in differences in environmental factors, such as light intensity, temperature, and plant density (Ludwig et al., 1965; King and Evans, 1967). For species with steeply inclined leaves (and consequently high light penetration), much higher LAI values can be expected, without any reduction in total photosynthetic productions, than for species with a flat leaf arrangement (Fig. 9-2). Moreover, differences in respiration rates may contribute to the varying experimental results. According to the models of Davidson and Philip (1958) and of Verhagen, Wilson, and Britten (1963), a reduction in the rate of net photosynthetic production is to be expected beyond a certain LAI value, since a constant value of respiration rate is attributed to all leaves. This assumption is rather doubtful, however, and direct estimates, as well as indirect evidence, have shown that the dark respiration rates of the bottom leaves in the canopy often are much lower than those of the top leaves (Ludwig et al., 1965; King and Evans, 1967). The bottom leaves are thus not parasitic in the sense of Nichiporovich (1956) and Davidson and Philip (1958) and will consequently not reduce the amount of assimilates produced by the top leaves to any greater extent. Moreover, the existence of photorespiration does steepen the gradient in respiration rates down the canopy still more (King and Evans, 1967), and will therefore contribute to reducing the occurrence of an optimal LAI under most conditions. 


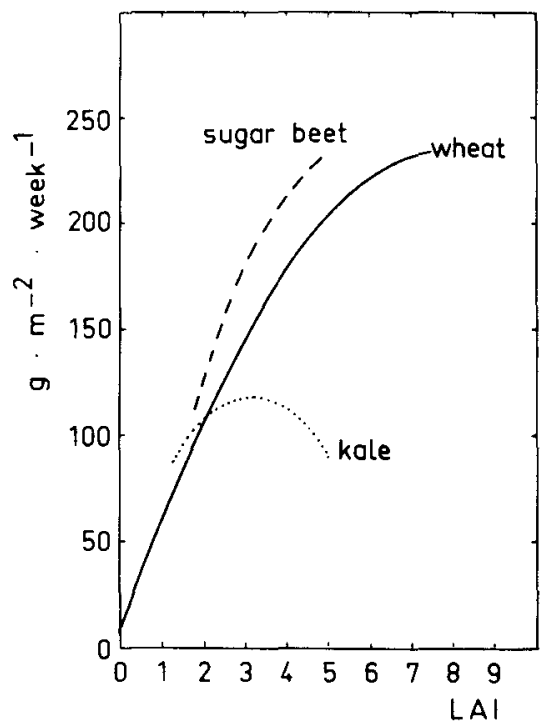

Fig. 9-2-The dependence of crop growth rate (C) on leaf area index (LAI). The data for kale and sugar beet are taken from Watson (1958), those for wheat from Stoy (1965).

\section{THE INFLUENCE OF METABOLIC SINKS ON THE RATE OF PHOTOSYNTHESIS}

\section{A. Experimental Evidence}

When rates of photosynthesis are determined experimentally in the laboratory (and of ten even the field) for a given set of external conditions, they are frequently thought to represent specific values that are characteristic for the species and the conditions in question. However, this is certainly only rarely true. In most cases the figures obtained are maximum values that are only seldom reached under natural conditions and then only during limited periods. The reason for this behavior is that even when plants are growing under very constant external conditions internal regulation may occur that modifies the response of the plants to a great extent (see, e.g., Went, 1958). Also the respiration rates of the different living tissues are influenced by internal factors and may vary considerably during the lifetime of a plant (Kidd, West, and Briggs, 1921).

If plants are manipulated so that their normal assimilate distribution is disturbed, it is possible to change the rate of photosynthesis in their green parts rather drastically even if the plants are growing under constant external conditions. If, for instance, the tubers of a potato (Solanum tuberosum L.) plant (Burt, 1964; Nossberger and Humphries, 1965), the grains of a wheat plant (King, Wardlaw, and Evans, 1967) 


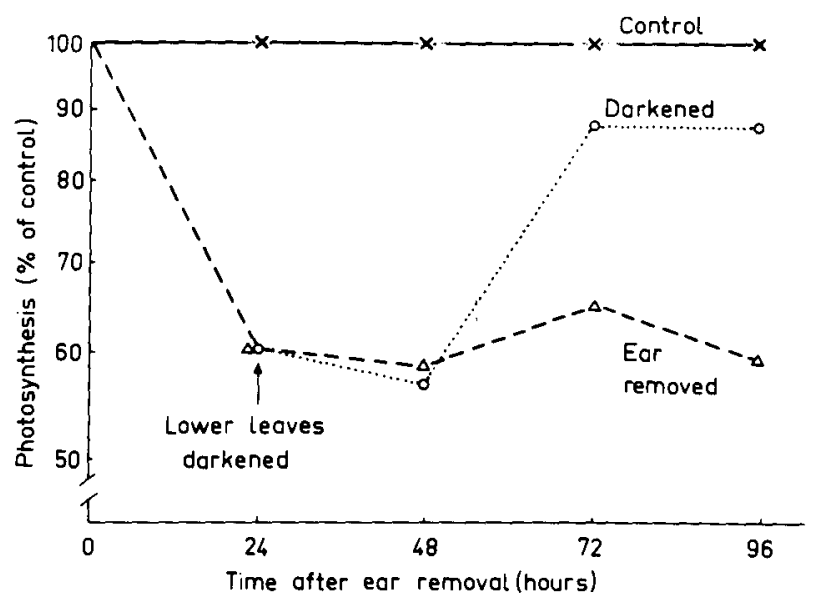

Fig. 9-3-The rate of net photosynthesis of wheat flag leaves after different treatments of the plants (From King, Wardlaw, and Evans 1967).

(cf. Fig. 9-3), the apples from an apple (Malus sylvestris) tree (Maggs, 1963; Hansen, 1967; see also Kazaryan, Balegezyan, and Karapetyan, 1965), or the fruits from a tomato (Lycopersicon esculentum Mill.) plant (Moss, 1962b) are removed soon after their appearance, the rate of photosynthesis in the leaves of these plants is decreased very significantly. Similarly, barren plants show a much lower photosynthetic rate than corresponding fertile specimens (Moss, 1962b).

Experiments in which the size of the source, instead of that of the sink, has been decreased have yielded reversed results. It has thus been reported that removing part of the leaves on maize plants (Kiesselbach, 1948; Wareing, Khalifa, and Treharne, 1968), apple trees (Maggs, 1964, 1965), pine (Pinus sp.) trees (Sweet and Wareing, 1966), and bean (Phaseolus sp.) or willow (Salix sp.) plants (Wareing et al., 1968) does very markedly increase the rate of photosynthesis in the remaining leaves. This increase may compensate for the loss of part of the green foliage, and has therefore been regarded by most authors as a response of the source to the demands of the sink.

\section{B. Possible Mechanisms to Explain Sink Action}

Two main theories have been advanced to explain the regulating ability of the sink-one rather old theory and a second more recent one.

One hundred years ago Boussingault (1868) proposed that the accumulation of assimilates in illuminated leaves might inhibit the rates of photosynthesis in the latter but it has still not been possible to prove or disprove this theory in a convincing manner (a thorough review of the problem is presented by Neales and Incoll, 1968). Several workers (e.g., Kurssanov, 1933; Went, 1958) have, however, adopted this idea and believe that removal of a metabolic sink induces a building-up of assim- 
ilates in the leaves, which in turn cause a reduction in the rate of photosynthesis.

According to a more recent hypothesis, the sink under normal conditions produces a certain amount of plant hormones that are translocated to the leaves where they increase the rate of photosynthesis. If the sink is disturbed or destroyed in any way, the amount of released hormones decreases, and, consequently, the rate of photosynthesis goes down (Sweet and Wareing, 1966; Bidwell and Turner, 1966).

The two theories have also been combined into a single one by assuming that growth regulators, produced in the sink, stimulate the flow of assimilates into the latter and thus prevent the accumulation of photosynthetic products that might depress the rate of photosynthesis at the source (Seth and Wareing, 1967; Hew, Nelson, and Krotkov, 1967).

Wareing et al. (1968) also found in their experiments that if the size of the green foliage was reduced, the activity of the carboxylating enzymes (ribulose-1,5-diphosphate carboxylase for beans and phosphoenolpyruvate carboxylase for maize) was raised significantly in the remaining leaves (Table 9-2). Based on this, they advanced the hypothesis that removal of part of the leaves stimulated the synthesis of proteinsand even enzymes-by reducing the competition for nutrients or growth substances.

Positive effects of treatment with growth substances on the rate of photosynthesis have been reported both for indole-3-acetic acid (Turner and Bidwell, 1965) and for gibberellin (Coulombe and Paquin, 1959; Alvim, 1960; Treharne and Stoddart, 1968), but many negative results have also been obtained (for a discussion see Hoffmann, 1968) and it is not clear, at the moment, whether growth substances actually exert a direct influence on photosynthesis or if their effects mainly are indirect, e.g., by an increased rate of translocation. However, Treharne and Stoddart (1968) found a close correlation in experiments with red clover (Trifolium pratense L.) between photosynthetic rate, activity of RuDP-carboxylase, and endogenous level of gibberellin in the leaves, a result that is suggestive of a direct influence on the photosynthesis rate in this case.

Table 9-2-Effect of partial defoliation on carboxylation reaction in remaining leaves. Enzyme activity was measured 3 days after defoliation (After Wareing, Khalifa, and Treharne, 1968)

\begin{tabular}{llcc}
\hline \multicolumn{1}{c}{ Material } & \multicolumn{1}{c}{ Treatment } & $\begin{array}{c}\text { Relative enzyme } \\
\text { activity }\end{array}$ & $\begin{array}{c}\text { Relative enzyme activity } \\
\text { per unit leaf area }\end{array}$ \\
\hline Phaseolus, RuDP & Control & 50.58 & 10.1 \\
carboxylase & Partial defoliation & 59.28 & 11.9 \\
Zea, PEP- & Control & 398.0 & 39.8 \\
carboxylase & Partial defoliation & 466.0 & 46.6 \\
\hline
\end{tabular}




\section{GROWTH AND THE DISTRIBUTION OF PHOTOSYNTHETIC PRODUCTS}

\section{A. The Distribution Pattern}

Only a minor fraction of the products of photosynthesis remain at the site of production in fully expanded leaves, most of them are translocated to other organs where they are either used as building-blocks for various cell-constituents or deposited as storage products. A certain part is always lost through respiration during transport and at the final storage site.

Numerous investigations have clearly demonstrated that the translocation of photosynthates within the plant does not occur in a random fashion but that a very definite distribution pattern can be recognized (cf. reviews by Brouwer, 1962; Wardlaw, 1968). This pattern of movement changes continuously during the growth of the plant and exerts a profound effect on both the morphological form and the yielding properties of the plant. It is therefore of great interest for the plant physiologist, as well as for the agronomist, to know the manner in which the pattern changes, and also how these changes are regulated and controlled.

During the development of a single leaf, we can distinguish stages with different patterns of assimilate movement. When the leaf is very young, it imports photosynthetic products from other parts of the plant to build up its own structure; but very soon it becomes self-supporting and in a short time starts to export assimilates (see, e.g., Jones, Martin, and Porter, 1959; Shiroya et al., 1961; Thrower, 1962; Joy, 1964). As long as the plant is young this export is mainly directed towards centers of active growth, such as developing leaves, root tips, or shoot apices; but later on much of the assimilate transport is diverted to storage organs, such as fruits, grains, or tubers. This shift in direction may be rather sudden and dramatic as is shown by Fig. 9-4, which illustrates the flow of assimilates in a cereal plant at different periods after ear emergence.

Another expression of the distribution pattern is the fact that leaves in different positions on the plant may preferentially supply different growing organs with assimilates (Belikov, 1955, Belikov and Kostetskii, 1964; Fujiwara and Suzuki, 1957; Quinlan and Sagar, 1962; Stoy, 1963; Williams, 1964; Wardlaw, 1965; Bonnemain, 1966; Lupton, 1966). The photosynthates for the roots are thus mainly produced in the lower leaves and those for the apical parts in the upper leaves, whereas leaves in an intermediate position deliver assimilates in both directions. This general pattern is only relative, however, and may be modified both by external conditions, such as temperature or water supply and by differences in the internal organization of the vascular system (cf. Wardlaw, 1968). 


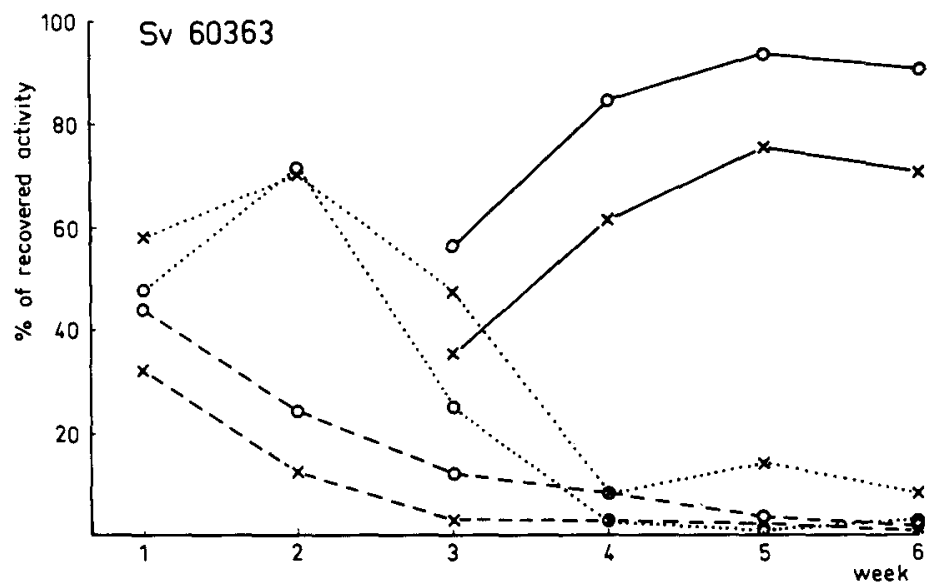

Fig. 9-4-The distribution of ${ }^{14} \mathrm{C}$-photosynthates from the upper two leaves during the period from ear emergence to leaf senescence in spring wheat (Sv 60363); 7 days translocation period. - grains, $--_{--}=$ears (minus grains), and . . . stems. Circles (o) represent photosynthates from the flag leaf and crosses (x) photosynthates from the second leaf from the top. (Unpublished results by Stoy).

\section{B. Regulation of the Flow of Assimilates}

There can hardly be any doubt that the centers of growth within the plants exert some attractive force on the flow of assimilates from the source to the sink (Aronoff, 1955; Crafts, 1961), and this force appears to determine both the direction and the intensity of the flow. Thus, different centers may exhibit various strengths of "demand" for assimilates, and therefore reproductive organs often (but not always!) dominate vegetative ones; shoot apices dominate root tips, etc.

The activity of the source, although not without importance, seems to be of secondary importance in this connection. This view is supported by the fact, amongst others, that several external factors, which may change the distribution pattern considerably (such as temperature or supply of water and nutrients) have a much greater influence on the rate of growth than on the rates of photosynthesis or translocation (Hsia, Waon, and Wang, 1963; Evans, Wardlaw, and Williams, 1964; Wardlaw, 1967,1968 ).

Although the importance of active growth for the establishment of a polar movement of assimilates thus seems to be generally accepted, there does not exist any corresponding agreement as to the mechanism by which the attracting force of the sink is mediated. This is obviously due to the fact that we still do not know with certainty the mechanism that initiates, directs, and regulates the basic translocation process. The older theories of a passive mass flow along a concentration gradient are rejected by most workers and explanations involving an active loading and unloading of the phloem system are preferred by the majority (cf. Zimmermann, 1960; Kurssanov, 1963; Schumacher, 1967). In 
this connection, an action of growth substances has been postulated by many authors (De Stigter, 1961; Crane, 1964; Hew et al., 1967) and comparisons with the attracting effect of cytokinins on amino acids (Mothes, Engelbrecht, and Kulajewa, 1959) have frequently been made.

\section{THE DEPENDENCE OF YIELD ON PHOTOSYNTHETIC ACTIVITY}

It may be appropriate at this stage, to recall that yield in the agronomic sense in most cases is not equivalent to total dry-matter production, but only to a certain fraction of the latter. However, this fraction is not constant even for a particular crop, but may change both with the environment and the genotype of the plant. An increase of this fraction can therefore be achieved by applying methods of plant husbandry, as well as of plant breeding.

In a recent book on the evolution of our cultivated plants, Schwanitz (1967) emphasizes strongly that the most outstanding feature of the evolution of the original wild forms into our present-day cultivated forms is the enormous increase in size of those parts of the plants that have come to be of special interest to man (Fig. 9-5). This nonuniform (allometric) growth is sometimes accompanied by a conspicuous enlargementalso of the photosynthetically active organs (cf. Fig. 9-6), but in most cases this is not so and instead a remarkable increase in the photosynthetic efficiency of these organs obviously has been achieved in the course of evolution. This does not necessarily mean, however, that the maximum values of photosynthetic rate have been raised to any large extent; a more likely explanation is that in the wild forms (and even in many of the cultivated forms) photosynthesis proceeds at a considerably lower rate than is envisaged by its potential upper limit (von Sengbusch,

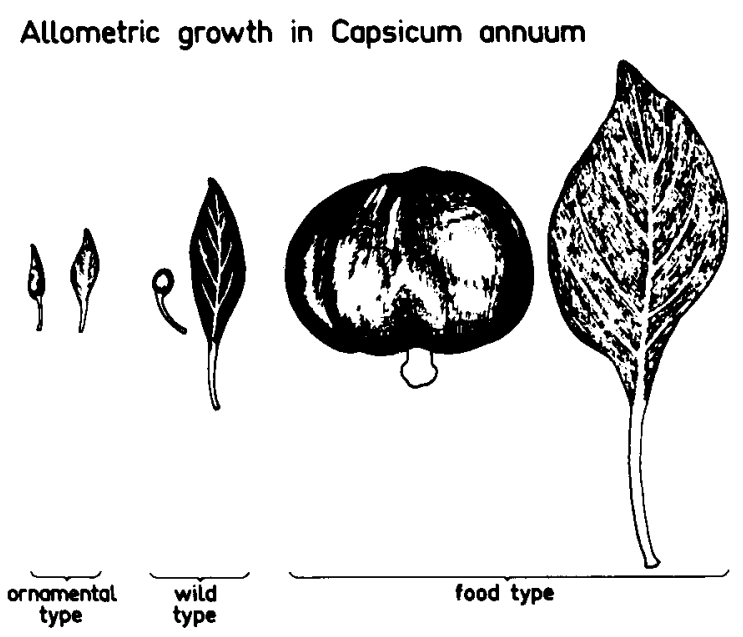

Fig. 9-5-A typical example of allometric growth in a cultivated plant (After Schwanitz, 1967). 


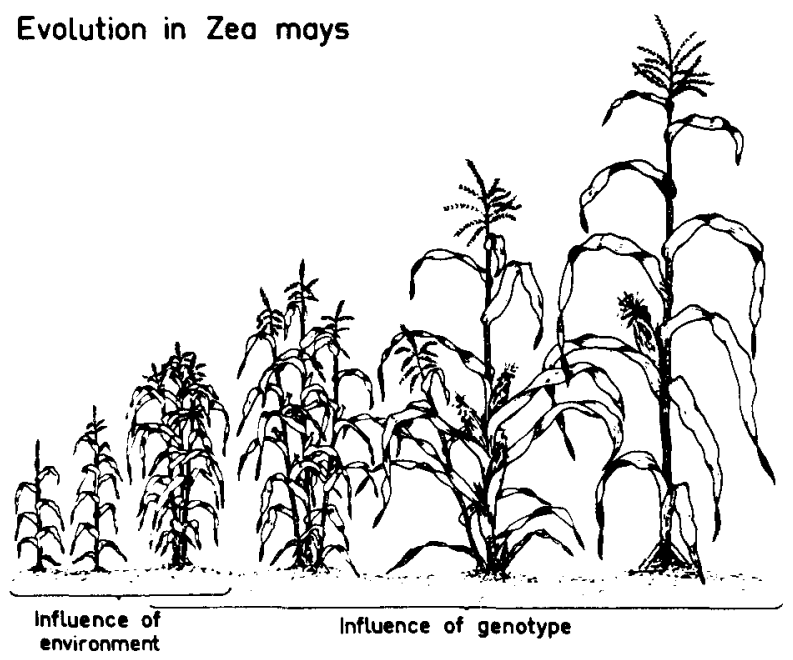

Fig. 9-6-Schematic representation of the relative importance of environmental and genotypical influences on the evolution of the maize plant (After Mangelsdorf, 1958).

1956; Went, 1958; Schwanitz, 1960) and that in the more high-yielding forms the actual rate of photosynthesis is closer to the potential limit.

The appreciable increase in yielding ability of these plants-when under cultivation, and thus subjected to a more or less conscious selection-may therefore be mainly attributed to an increased growth rate in particular organs, which is accompanied by a stronger flow of assimilates to these parts, as well as by a higher efficiency of the already existing photosynthetic apparatus. This evolutionary process should not be considered as terminated; there are, on the contrary, clear indications that it is still going on also in highly bred crops (van Dobben, 1962; Sandfaer, Jørgensen, and Haahr, 1965); but it should also be pointed out that in order to raise the maximum yielding capacity beyond its present level, it may be necessary in many cases to increase both the specific rate of photosynthesis and the fraction of total production that is diverted into those organs that are to be harvested (Nichiporovich, 1956; Donald, 1962; Stoy, 1965).

\section{CHALLENGES FOR THE FUTURE}

In concluding this lecture, I would like to draw attention to some of the problems just discussed that I believe deserve a particularly intensive study. One such problem regards photorespiration. We urgently need to know its exact biochemical nature and why it seems to be absent in some species. Of special importance is the question whether this lack is only apparent (due to rapid recycling of $\mathrm{CO}_{z}$ ) or if it depends on a real biochemical difference among species. Thus a flux of $\mathrm{CO}_{2}$ back to the atmosphere is equivalent to a loss of trapped energy and must therefore be prevented as much as possible. In this connection, it is 
also of great importance to learn if photorespiration has any essential function in plant life or not. If photorespiration is really absent in some species, it is hard to believe that it can play any vital role, particularly since these species include some of the most productive ones in the whole world.

Related to this problem is the question if it may be possible to convert, by methods of plant breeding, high-compensating plants into lowcompensating ones? To answer this question, it seems to be necessary to know whether the phenomenon of light-dependent $\mathrm{CO}_{2}$ evolution is closely linked to any specific anatomical features or if it is primarily caused by biochemical processes. The prospects for successful plant breeding seem to be considerably better in the latter case.

Another existing problem is to find out how near to potential photosynthetic production we can really come with different crops (and even varieties). For certain crops and at certain stages of development the limit has perhaps already been reached (cf. Stoy, 1966), but for others there seems to exist a fairly wide gap between what theoretically may be produced and what is actually achieved. The reasons for this discrepancy may be of different kinds; besides such obvious external influences as lack of water or nutrients, internal factors such as an inadequate assimilate distribution and inhibited rate of photosynthesis, or both , may be involved (Ermilov, 1962). In order to increase the productivity of the crop, it may, therefore, sometimes be desirable to effect a more or less radical change in the morphology and physiology of the plants. Plant breeding appears to be the method of choice to produce such changes (e.g., the tremendous success of the semidwarf varieties in wheat and rice) but the use of externally applied growthregulators sometimes also gives spectacular results.

It is a distressing fact that we lack the basic physiological information in most cases to answer these questions. It is also embarrassing that we often know very little, for example, about the differences between species and varieties even with regard to major physiological processes and how they proceed quantitatively. There is a definite trend throughout the world, however, to try to fill the existing gaps in our knowledge in this particular respect, and it is to be hoped that within a relatively few years we will be able to understand much better the way in which different crop plants absorb, distribute, and store the energy they derive from the sun and how to utilize this information to produce more food for mankind.

\section{LITERATURE CITED}

Alvim, P. de T. 1960. Net assimilation rate and growth behavior of beans as affected by gibberellic acid, urea, and sugar sprays. Plant Physiol. 35:285288.

Aronoff, S. 1955. Translocation from soybean leaves. Plant Physiol. 30:184-185.

Belikov, I. F. 1955. Movement and distribution of photosynthetic products in soybean plants during the vegetation period (In Russian). Fiziol. Rast. : 4:345-357.

Belikov, I. F., and E. Ya. Kostetskii. 1964. The distribution of assimilates in sugar beet during the growth period. Soviet Plant Physiol. 11:508-511. 
Bidwell, R. G. S., and Wendy B. Turner. 1966. Effect of growth regulators on $\mathrm{CO}_{2}$ assimilation in leaves, and its correlation with the bud break response in photosynthesis. Plant Physiol. 41:267-270.

Björkman, O. 1967. Further studies of the effect of oxygen concentration on photosynthetic $\mathrm{CO}_{z}$ uptake in higher plants. Carnegie Inst. Washington Yearbook $66: 310-318$.

Black, J. N. 1963. The interrelationship of solar radiation and leaf area index in determining the rate of dry matter production of swards of subterranean clover (Trifolium subterraneum L.). Aust. J. Agr. Res. 14:20-38.

Bonnemain, M. J. 1966. Sur les transport des produits de la photosynthèse chez la Tomate lors de la fructification. Compt. Rend. Acad. Sci. (Paris) 262:366369 .

Boussingault, J. B. 1868. Agronomie, chimie agricole et physiologie. $2^{\mathrm{e}}$ Ed. Mallet Bachelier, Paris, 1860-1874, 5 vols. (p. 236-312).

Brix, H. 1968. Influence of light intensity at different temperatures on rate of respiration of Douglas-fir seedlings. Plant Physiol. 43:389-393.

Brougham, R. W. 1956. Effect of intensity of defoliation on regrowth of pasture. Aust. J. Agr. Res. 7:377-387.

Brouwer, R. 1962. Distribution of dry matter in the plant. Neth. J. Agr. Sci. 10 (Special Issue) :361-376.

Burt, R. L. 1964. Carbohydrate utilization as a factor in plant growth. Aust. J. Biol. Sci. 17:867-877.

Coulombe, L.-J. et R. Paquin. 1959. Effects de l'acide gibberellique sur le métabolisme des plantes. Can. J. Bot. 37:897-901.

Crafts, A. S. 1961. Translocation in plants. Holt, Rinehart, and Winston, New York. $182 \mathrm{p}$.

Crane, J. C. 1964. Growth substances in fruit setting and development. Ann. Rev. Plant Physiol. 15:303-326.

Davidson, J. L., and C. M. Donald. 1958. The growth of swards of subterranean clover with particular reference to leaf area. Aust. J. Agr. Res. 9:53-72.

David son, J. L. and J. R. Philip. 1958. Light and pasture growth, p. 181-187. In Climatology and microclimatology, Proc. Canberra Symp. 1956, Unesco, Paris.

Decker, J. P. 1955. A rapid, postillumination deceleration of respiration in green leaves. Plant Physiol. 30:82-84.

De Stigter, H. C. M. 1961. Translocation of ${ }^{14} \mathrm{C}$-photosynthates in the graft muskmelon (Cucurbita ficifolia). Acta Bot. Neerl. 10:466-473.

Dobben, W. H. van. 1962. Influence of temperature and light conditions on drymatter distribution, development rate and yield in arable crops. Neth. J. Agr. Sci. 10 (Special Issue) :377-388.

Donald, C. M. 1962. In search of yield. J. Aust. Inst. Agr. Sci. 28:171-178.

Downton, W. J. S., and E. B. Tregunna. 1968a. Photorespiration and gycolate metabolism: A re-examination and correlation of some previous studies. Plant Physiol. 43:923-929.

Downton, W. J. S., and E. B. Tregunna. 1968b. Carbon dioxide compensation its relation to photosynthetic carboxylation reactions, systematics of the Graminae, and leaf anatomy. Can. J. Bot. 46:207-215.

Egle, K., and G. Döhler 1963. Uber Induktionserscheinungen der Photosynthese und der Lichtatmung bei einzelligen Grünalgen. Beitr. Biol. Pfl. 42:213-239.

El-Sharkawy, M. A., and J. D. Hesketh. 1964. Effects of temperature and water deficit on leaf photosynthetic rates of different species. Crop Sci. 4:514-518.

El-Sharkawy, M. A., and J. D. Hesketh. 1965. Photosynthesis among species in relation to characteristics of leaf anatomy and $\mathrm{CO}_{2}$ diffusion resistances. Crop Sci. 5:517-521.

El-Sharkawy, M. A., Loomis, R. S., and W. A. Williams. 1967. Apparent reassimilation of respiratory carbon dioxide by different plant species. Physiol. Plant. 20:171-186. 
Ermilov, G. B. 1962. Dependence of leaf productivity of corn on the internal plant processes. Soviet Plant Physiol. 9:315-317.

Evans, L. T., I. F. Wardlaw, and C. N. Williams. 1964. Environmental control of growth, p. 102-125. In C. Barnard (ed.) Grasses and grasslands. Macmillan, London.

Fock, H., and K. Egle. 1966. Über die "Lichtatmung" bei grünen Pflanzen. I. Die Wirkung von Sauer stoff und Kohlendioxyd auf den $\mathrm{CO}_{2}$-Gaswechsel während der Licht- und Dunkelphase. Beitr. Biol. Pfl. 42:213-239.

Fock, H., H. Schaub, und W. Hilgenberg. 1969. Über den Sauer stoffund Kohlendioxidgaswechsel von Chlorella und Conocephalum während der Lichtphase. Z.f.Pflanzenphysiol. $60: 56-63$.

Forrester, Marlene L., G. Krotkov, and C. D. Nelson. 1966a. Effect of oxygen on photosynthesis, photorespiration and respiration in detached leaves. I. Soybean. Plant Physiol. 41:422-427.

Forrester, Marlene L., G. Krotkov, and C. D. Nelson. 1966b. Effect of oxygen on photosynthesis, photorespiration and respiration in detached leaves. II. Corn and other monocotyledons. Plant Physiol. 41:428-431.

Fujiwara, A., and M. Suzuki. 1957. Studies on the carbon metabolism in higher plants. II. Structural distribution of the carbon-14 absorbed through the leaf in the rice plant. Tohoku J. Agr. Res. 8:89-97.

Goldsworthy, A. 1966. Experiments on the origin of $\mathrm{CO}_{2}$ released by tobacco leaf segments in the light. Phytochem. 5:1013-1019.

Hansen, P. 1967. 14 C-studies on apple trees. I. The effect of the fruit on the translocation and distribution of photosynthates. Physiol. Plant. 20:382-391.

Hatch, M. D., and C. R. Slack. 1966. Photosynthesis by sugarcane leaves. A new carboxylation reaction and the pathway of sugar formation. Biochem. J. 101:103-111.

Hatch, M. D., C. R. Slack, and Hilary S. Johnson. 1967. Further studies on a new pathway of photosynthetic carbon dioxide fixation in sugarcane and its occurrence in other plant species. Biochem. J. 102:417-422.

Hesketh, J. 1967. Enhancement of photosynthetic $\mathrm{CO}_{2}$-assimilation in the absence of oxygen, as affected by species and temperature. Planta 76:371-374.

Hesketh, J., and D. Baker. 1967. Light and carbon assimilation by plant communities. Crop Sci. 7:285-293.

Hesketh, J. and D. N. Moss. 1963. Variation in the response of photosynthesis to light. Crop Sci. 3:107-110.

Hew, C., C. D. Nelson, and G. Krotkov. 1967. Hormonal control of translocation of photosynthetically assimilated ${ }^{14} \mathrm{C}$ in young soybean plants. Amer. J. Bot. 54:252-256.

Hoch, G., Olga v. H. Owens, and B. Kok. 1963. Photosynthesis and respiration. Arch. Biochem. Biophys, 101:171-180.

Hoffman, P. 1968. Zur Physiologie der Photosynthese bei höheren Pflanzen. Botanische Studien. 18. VEB Gustav Fischer, Jena. $151 \mathrm{p}$.

Holmgren, P., and P. G. Jarvis. 1967. Carbon dioxide efflux from leaves in light and darkness. Physiol. Plant. 20:1045-1051.

Hsia, C.-A., S.-S. Waon, and F.-T. Wang. 1963. The influence of temperature on the physiological changes in wheat during the grain formation stage (In Chinese with English summary). Acta Bot. Sinica. 11:338-349.

Joliffe, P. A., and E. B. Tregunna. 1968. Effect of temperature, $\mathrm{CO}_{2}$ concentration, and light intensity on oxygen inhibition of photosynthesis in wheat leaves. Plant Physiol. 43:902-906.

Jones, H., R. V. Martin, and Helen K. Porter. 1959. Translocation of ${ }^{14}$ carbon in tobacco following assimilation of ${ }^{14}$ carbon dioxide by a single leaf. Ann. Bot. N.S. 23:493-508.

Joy, K. W. 1964. Translocation in sugar beet. I. Assimilation of ${ }^{14} \mathrm{CO}_{2}$ and distribution of materials from leaves. J. Exptl. Bot. 15:485-494.

Kazaryan, V. O., N. V. Balagezyan, and K. A. Karapetyan. 1965. Influence of the fruits of apple trees on the physiological activity of the leaves. Soviet Plant Physiol. 12:265-269. 
Kidd, F., C. West, and G. E. Briggs. 1921. A quantitative analysis of the growth of Helianthus annuus. Part I. The respiration of the plant and its parts throughout the life cycle. Proc. Roy. Soc. London. Ser. B. 92:368-384.

Kiesselbach, T. A. 1948. Endosperm type as a physiological factor in corn yield. J. Amer. Soc. Agron. 40:216-236.

King, R. W., and L. T. Evans. 1967. Photosynthesis in artificial communities of wheat, lucerne, and subterranean clover plants. Aust. J. Biol. Sci. 20:623-635.

King, R. W., I. F. Wardlaw, and L. T. Evans. 1967. Effect of assimilate utilization on photosynthetic rate in wheat. Planta 77:261-276.

Kortschak, H. P., Constance E. Hartt, and G. O. Burr. 1965. Carbon dioxide fixation in sugarcane leaves. Plant Physiol. 40:209-213.

Kurssanov, A. L. 1933. Über den Einfluss der Kohlenhydrate auf den Tagesverlauf der Photosynthese. Planta 20:535-548.

Kurssanov, A. L. 1963. Metabolism and the transport of organic substance in the phloem. Advance Bot. Res. 1:209-278.

Ludwig, L. J., T. Saeki, and L. T. Evans. 1965. Photosynthesis in artificial communities of cotton plants in relation to leaf area. I. Experiments with progressive defoliation of mature plants. Aust. J. Biol. Sci. 18:1103-1118.

Lupton, F. G. H. 1966. Translocation of photosynthetic assimilates in wheat. Ann. Appl. Biol. 57:355-364.

Maggs, D. H. 1963. The reduction in growth brought about by fruiting. J. Hort. Sci. 38:119-128.

Maggs, D. H. 1964. Growth rates in relation to assimilate supply and demand. I. Lueaves and roots as limiting regions. J. Exp. Bot. 15:574-583.

Maggs, D. H. 1965. Growth rates in relation to assimilate supply and demand. II. The effect of particular leaves and growing regions in determining the dry matter distribution in young apple trees. J. Exp. Bot. 16:387-404.

Mangelsdorf, P. C. 1958. Reconstructing the ancestor of corn. Proc. Amer. Philos. Soc. 102 . No. 5.

Mansfield, T. A. 1968. Carbon dioxide compensation points in maize and Pelargonium. Physiol. Plant. 21:1159-1162.

McAlister, E. D., and J. Myers. 1940. The time course of photosynthesis and fluorescence observed simultaneously. Smithson. Misc. Coll. 99:6-26.

Meidner, $\mathrm{H}$. 1962. The minimum intercellular-space $\mathrm{CO}_{2}$-concentration $(\Gamma)$ of maize leaves and its influence on stomatal movements. J. Exp. Bot. 13:284293.

Moss, D. N. 1962a. The limiting carbon dioxide concentration for photosynthesis. Nature 193:587.

Moss, D. N. 1962b. Photosynthesis and barrenness. Crop Sci. 2:366-367.

Moss, D. N. 1966. Respiration of leaves in light and darkness. Crop Sci. 6:351354.

Moss, D. N. 1968. Photorespiration and glycolate metabolism in tobacco leaves. Crop Sci. 8:71-76.

Moss, D. N., R. B. Musgrave, and E. R. Lemon. 1961. Photosynthesis under field conditions: II. Some effects of light, carbon dioxide, temperature, and soil moisture on photosynthesis, respiration, and transpiration of corn. Crop Sci. 1:83-87.

Mothes, K., L. Engelbrecht, und O. Kulajewa. 1959. Über die Wirkung des Kinetins auf Stickstoffverteilung und Eiweissynthese in isolierten Blättern. Flora $147: 445-464$.

Murata, Y., and J. Iyama. 1963. Studies on the photosynthesis of forage crops. II. Influence of air-temperature upon the photosynthesis of some forage and grain crops. Proc. Crop Sci. Soc. Japan 31:315-322.

Neales, T. F., and L. D. Incoll. 1968. The control of leaf photosynthesis rate by the level of assimilate concentration in the leaf: A review of the hypothesis. Bot. Rev. 34:107-125.

Nichiporovich, A. A. 1956. Photosynthesis and the theory of obtaining high crop yields. 15th Timiryazev lecture. USSR Acad. Sci., Moscow. 94 p. (Engl. Trans1.: Dept. Sci. Industr. Res. Gt. Brit. 1959). 
Nichiporovich, A. A., and V. Malofeyev. 1965. Principles of the formation of highly productive photosynthesizing systems. Soviet Plant Physiol. 12:1-8.

Nösberger, J., and E. C. Humphries. 1965. The influence of removing tubers on dry matter production and net assimilation rate of potato plants. Ann. Bot. N.S. $29: 579-588$.

Ozbun, J. L., R. J. Volk, and W. A. Jackson. 1964. Effects of light and darkness on gaseous exchange of bean plants. Plant Physiol. 39:523-527.

Poskuta, J. 1968. Photosynthesis, photorespiration and respiration of detached spruce twigs as influenced by oxygen concentration and light intensity. Physiol. Plant. 21:1129-1136.

Poskuta, J., C. D. Nelson, and G. Krotkov. 1967. Effects of metabolic inhibitors on the rates of $\mathrm{CO}_{2}$ evolution in light and in darkness by detached spruce twigs, wheat and soybean leaves. Plant Physiol. 42:1187-1190.

Quinlan, J: D., and G. R. Sagar. 1962. An autoradiographic study of the movement of ${ }^{14} \mathrm{C}$-labelled assimilates in the developing wheat plant. Weed Res. 2:264-273.

Rabinowitch, E. I. 1945. Photosynthesis and related processes. I. Interscience Publ., New York. 602 p.

Rhoades, N. M., and A. Carvalho. 1944. The function and structure of the parenchyma sheath plastids of the maize leaf. Bull. Torrey Bot. Club 71:335-346.

Sandfaer, J., J. H. Jørgensen, and V. Haahr. 1965. The effect of nitrogen fertilization on old and new barley varieties. Roy. Vet. Agr. Coll. Yearbook 1965: $153-180$.

Schumacher, W. 1967. Die Fernleitung der Stoffe im Pflanzenkörper. In W. Ruhland (ed.) Handb.d.Pflanzenphysiol. XIII:61-177.

Schwanitz, F. 1960. Das Ertragsproblem in entwicklungsphysiologischer Sicht. Züchter 30:45-56.

Schwanitz, F. 1967. Die Evolution der Kulturpflanzen. BLV, München, Basel, Wien. $463 \mathrm{p}$.

Sengbusch, R. von. 1956. Untersuchungen über die Ursachen der Leistungen unserer Nahrungskulturpflanzen. Jb. Max-Planck-Ges. 200-209.

Seth, A. K., and P. F. Wareing. 1967. Hormone directed transport of metabolites and its possible role in plant senescence. J. Exp. Bot. 18:65-77.

Shibles, R. M., and C. R. Weber. 1965. Leaf area, solar radiation interception and dry matter production by soybeans. Crop Sci. 5:575-577.

Shiroya, T., G. R. Lister, C. D. Nelson, and G. Krotkov. 1961. Translocation of $\mathrm{C}^{14}$ in tobacco, at different stages of development following assimilation of $\mathrm{C}^{\mathrm{d4}} \mathrm{O}_{2}$ by a single leaf. Can. J. Bot. 39:855-864.

Slack, C. R., and M. D. Hatch. 1967. Comparative studies on the activity of carboxylases and other enzymes in relation to the new pathway of photosynthetic carbon dioxide fixation in tropical grasses. Biochem. J. 103:660-665.

Stoy, V. 1963. The translocation of the $\mathrm{C}^{14}$-labelled photosynthetic products from the leaf to the ear in wheat. Physiol. Plant. 16:851-866.

Stoy, V. 1965. Photosynthesis, respiration, and carbohydrate accumulation in spring wheat in relation to yield. Physiol. Plant. Suppl. IV:1-125.

Stoy, V. 1966. Photosynthetic production after ear emergence as yield-limiting factor in the culture of cereals. Acta Agr. Scand. Suppl. 16:178-182.

Sweet, G. B., and P. F. Wareing. 1966. Role of plant growth in regulating photosynthesis. Nature 210:77-79.

Thrower, Stella L. 1962. Translocation of labelled assimilates in soybean. II. The pattern of translocation in intact and defoliated plants. Aust. J. Biol. Sci. $15: 629-649$.

Tregunna, B. 1966. Flavin mononucleotide control of glycolic acid oxidase and photorespiration in corn leaves. Science 151:1239-1241.

Tregunna, G., G. Krotkov, and C. D. Nelson. 1961. Evolution of carbon dioxide by tobacco leaves during the dark period following illumination with light of different intensities. Can. J. Bot. 39:1045-1056.

Tregunna, B., G. Krotkov, and C. D. Nelson. 1964. Further evidence on the effects of light on respiration during photosynthesis. Plant Physiol. 42:989-997. 
Tregunna, B., G. Krotkov, and C. D. Nelson. 1966. Effect of oxygen on the rate of photorespiration in detached tobacco leaves. Physiol. Plant. 19:723-733.

Treharne, K. J., and J. L. Stoddart. 1968. Effects of gibberellin on photosynthe sis in red clover (Trifolium pratense L.). Nature 220:457-458.

Turner, Wendy B., and R.G.S. Bidwell. 1965. Rates of photosynthesis in attached and detached bean leaves, and the effect of spraying with indoleacetic acid solution. Plant Physiol. 40:446-451.

Turner, J. S., and Brittain, E. G. 1962. Oxygen as a factor in photosynthesis. Biol. Rev. 37:130-170.

Verhagen, A. M. W., J. H. Wilson, and E. J. Britten. 1963. Plant production in relation to foliage illumination. Ann. Bot. N. S. 27:627-640.

Wang, T. D. and J. Wei. 1964. The $\mathrm{CO}_{2}^{-}$assimilation rate of plant communities as a function of leaf area index. Acta Bot. Sinica 12:154-158.

Warburg, O. 1920. Über die Geschwindigkeit der photochemischen Kohlensäurezersetzung in lebenden Zellen. II. Biochem. Z. 103:188-217.

Wardlaw, I. F. 1965. The velocity and pattern of assimilate translocation in wheat plants during grain development. Aust. J. Biol. Sci. 18:269-281.

Wardlaw, I. F. 1967. The effect of water stress on translocation in relation to photosynthesis and growth. I. Effect during grain development in wheat. Aust. J. Biol. Sci. 20:25-39.

Wardlaw, I. F. 1968. The control and pattern of movement of carbohydrates in plants. Bot. Rev. 34:79-105.

Wareing, P. F., M. M. Khalifa, and K. J. Treharne. 1968. Rate-limiting processes in photosynthesis at saturating light intensities. Nature 220:453-457.

Watson, D. J. 1958. The dependence of net assimilation rate on leaf area index. Ann. Bot. N.S. 22:37-54.

Watson, D. J., Gillian N. Thorne, and S. A.W. French. 1963. Analysis of growth and yield of winter and spring wheats. Ann. Bot. N.S. 27:1-22.

Went, F. W. 1958. The physiology of photosynthesis in higher plants. Preslia $1: 225-240$.

Wilfong, R. T., R. H. Brown, and R. E. Blaser. 1967. Relationships between leaf area index and apparent photosynthesis in alfalfa (Medicago sativa L.) and Ladino clover (Trifolium repens L.). Crop Sci. 7:27-30.

Williams, R. D. 1964. Assimilation and translocation in perennial grasses. Ann. Bot. N.S. 28:419-426.

Williams, W. A., R. S. Loomis, and C. R. Lepley. 1965. Vegetative growth of corn as affected by population density. II. Components of growth, net assimilation rate and leaf area index. Crop Sci. 5:215-219.

Zelitch, I. 1958. The role of glycolic acid oxidase in the respiration of leaves. J. Biol. Chem. 233:1299-1303.

Zelitch, I. 1959. The relationship of glycolic acid to respiration and photosynthe sis in tobacco leaves. J. Biol. Chem. 234:3077-3081.

Zelitch, I. 1966. Increased rate of net photosynthetic carbon dioxide uptake caused by the inhibition of glycolate oxidase. Plant Physiol. 41:1623-1631.

Zimmermann, M. H. 1960. Transport in the phloem. Ann. Rev. Plant. Physiol. 11:167-190. 


\section{$9 \ldots$ DIscussion}

DALE N. MOSS

University of Minnesota

St. Paul, Minnesota

For a long time I have admired Dr. Stoy's scholarly and thorough work. His presentation this morning has done nothing to detract from that esteem. In the time allotted to me I would like to enlarge on three points which he has discussed in his paper. First, let us consider the topic of chloroplast arrangement in low compensation and high photosynthetic efficiency species. Some years ago Paul Rasmussen and I were interested in where, within leaves, $\mathrm{CO}_{2}$ was being fixed and how the pattern of fixation was affected by internal shading, stomatal arrangement, etc. We fed illuminated leaves a short burst of ${ }^{14} \mathrm{CO}_{2}$, quickly froze the tissue in isopentane cooled in liquid $\mathrm{N}$, freeze-dried the tissue, and determined where the ${ }^{14} \mathrm{CO}_{2}$ was located, which, presumably, would still be in the cells where it was originally fixed. To our surprise we found that, in contrast to the widespread fixation in all green cells in sugar beet (Beta vulgaris L.) (a high $\mathrm{CO}_{z}$ compensation species), corn (Zea mays L.) (a low compensator) fixed its $\mathrm{CO}_{2}$ in cells surrounding the vascular bundles. (Unknown to us, a somewhat similar experiment was done with corn and barley (Hordeum vulgare L.) by N.A. Pristupa in Moscow, Fiziologiya Rastenii 11:38-42, 1964). We now know that these bundle-sheath cells contain specialized chloroplasts which differ markedly in ultrastructure from chloroplasts in mesophyll cells. These can be separated from other mesophyll chloroplasts by density gradient centrifugation and we are studying their physiology.

This fixation pattern raises some most interesting questions. Why do corn bundle sheath cells fix most of the $\mathrm{CO}_{2}$ during photosynthesis to the practical exclusion of other green mesophyll cells? Does the peculiar form of these bundle sheath chloroplasts have special meaning in terms of C-4 pathway of photosynthesis? If so does the Calvin cycle operate in the "normal"appearing chloroplasts of other mesophyll cells?

Such questions have special implications in terms of the second point I would like to consider, the inheritance of the efficient "corntype" photosynthesis. All evidence to date indicates that $\mathrm{CO}_{z}$ compensation concentrations are either less than $10 \mathrm{ppm}$ or greater than 40 ppm. If both Calvin and C-4 pathways should be found in corn this would mean that all the cells in a corn plant, and presumably, then, other plants as well, had the genetic potential for either system. Something about the environment of the corn bundle sheath, however, might dictate that the $\mathrm{C}-4$ pathway predominates in those cells. If low compensation points were the result, through affinity of enzymes for $\mathrm{CO}_{2}$, of the presence of a C-4 pathway both Calvin and C-4 pathways could be present but the $\mathrm{CO}_{2}$ compensation be controlled by $\mathrm{C}-4$ enzymes. 
The mode of inheritance of efficient photosynthesis is not known. Crosses between high and low compensation species and obtaining segregating populations would permit us to determine whether leaf anatomy, photorespiration, carbon pathway, etc., were all required for high rates of $\mathrm{CO}_{2}$ fixation or just which factors were the essential ones for efficient photosynthesis. Such crosses have never been made because high and low compensation has not been known in closely related species. In our laboratory we have classified several hundred species for compensation concentration, and in most cases, the taxonomic classification accurately predicts which photosynthetic system a plant will have. We have found four genera, however, which contain both high and low compensation species. We are attempting interspecific crosses between high and low compensating species to study the control mechanisms for these many interesting and correlated traits.

Finally to the subject of breeding plants for photosynthetic efficiency-You cannot look at a plant and tell the kind of photosynthetic mechanism it has and to measure $\mathrm{CO}_{2}$ uptake or $\mathrm{CO}_{2}$ compensations take much too much time to be practical as breeding tools. We have been seeking ways to rapidly screen individual plants for photosynthetic efficiency and we now have a method which is reliable and rapid and may be of interest to you. In our system we take advantage of the fact that plants which have the efficient corn-type photosynthesis are able to grow quite well in an atmosphere so deficient in $\mathrm{CO}_{2}$ that the nonefficient plant is below its compensation concentration. Thus, by growing together in a closed system, our test population to be screened and some low compensating plants such as corn or sorghum (Sorghum vulgare Pers.), the efficient plants keep the $\mathrm{CO}_{2}$ concentration below the compensation of inefficient plants. They survive on the $\mathrm{CO}_{2}$ being continually respired by the nonefficient plants. The nonefficient plants rapidly die. There is opportunity to spread the difference between efficient and nonefficient plants to very wide margins by increasing the $\mathrm{O}_{z}$ concentration and air temperature. If there were any efficient plants in our test population they would survive and grow as does the corn. This system is working very well for us and permits us to actively proceed with a breeding program to introduce high photosynthetic efficiency into nonefficient small grains.

If we can change the photosynthetic capacity of leaf tissue can we change the capacity to produce grain? I do not know of any example of yield differences among varieties or lines within a single species that can be attributed directly to differences in photosynthetic capacity. On the other hand, there is ample evidence that changing the photosynthetic rate does markedly alter yield. Consider, for example, the advantage of $\mathrm{CO}_{z}$ fertilization in glasshouses or the many experiments showing yield reductions due to shading. Would within-species material, differing in photosynthetic capacity, allow us to better evaluate the role of translocation, strength of sinks, or location with respect to sinks? These and other questions we hope to answer through genetic manipulation of some of these most interesting plant traits. 


\title{
9 ...DISCUSSION
}

\author{
GILLIAN N. THORNE
}

Rothamsted Experimental Station

Harpenden, Herts, England

It seems an appropriate place in this symposium to summarize the physiological characters of a high yielding crop, i.e., one that produces a large yield of the economically useful part rather than of total dry matter, and to discuss which physiological characters limit yields of particular crops.

Firstly, there must be plenty of l eaf surface arranged to use the available radiation efficiently (see R.S. Loomis, Chapter 3, this book). The leaf area at a particular time may be especially important. For example, in European wheat (Triticum aestivum L.) and barley (Hordeum vulgare L.) crops, grain yield is closely correlated with the leaf area after flowering but not with that earlier, because almost all the carbohydrate in the grain is produced by photosynthesis after flowering (Thorne, 1966). Secondly, the net $\mathrm{CO}_{2}$ uptake by the crop should be fast, which requires fast photosynthesis or slow respiration.

To accommodate the carbohydrate produced by the efficient leaves the crop must have an efficient sink. Sink capacity may affect the distribution of carbohydrate within the plant even when it has no or little effect on photosynthesis of the leaves, as often occurs in barley and wheat (Nösberger and Thorne, 1965; Thorne, Ford, and Watson, 1968). Although it can be shown experimentally that yield depends on adequate production of carbohydrate and an adequate sink to accept this, it is often difficult to decide whether supply or sink capacity is restricting yield in any particular situation. Both seem to control yield of wheat and barley in Britain. Evidence comes from a study of the apparent efficiency in grain production of the leaf area present after flowering (Welbank, Witts, and Thorne, 1968). The efficiency can be expressed as the ratio of grain yield to the leaf area duration between flowering and maturity. In controlled environments and in the field this ratio increases with increase in radiation, presumably because the leaves phosynthesize faster. It also increases with increase in temperature, although photosynthesis and total dry weight are not increased, probably because the grains grow faster and use more carbohydrate; i.e., they are a more efficient sink.

These suggestions about the physiological control of yield of wheat and barley apply to European varieties; the semidwarf varieties derived from the Japanese variety Norin 10 behave slightly differently. When grown in Britain, they have grain yields similar to European varieties but only about half the leaf area after flowering. We do not know whether 
the apparently greater efficiency of the leaves is caused by faster photosynthesis, less respiration, or more efficient translocation (Thorne, Welbank, and Blackwood, 1969).

\section{LITERATURE CITED}

Nösberger, J., and G. N. Thorne. 1965. The effect of removing florets or shading the ear of barley on production and distribution of dry matter. Ann. Bot. N.S. $29: 635-44$.

Thorne, G. N. 1966. Physiological aspects of grain yield in cereals, p. 88-105. In F. L. Milthorpe and J. D. Ivins (ed.). The growth of cereals and grasses. Butterworths, London.

Thorne, G. N., M. A. Ford, and D. J. Watson. 1968. Growth, development, and yield of spring wheat in artificial climates. Ann. Bot. N. S. 32:425-426.

Thorne, G. N., P. J. Welbank and G. C. Blackwood. 1969. Growth and yield of six short varieties of spring wheat derived from Norin 10 and of two European varieties. Ann. Appl. Biol. 63:241-251.

Welbank, P. J., K. J. Witts, and G. N. Thorne. 1968. Effect of radiation and temperature on efficiency of cereal leaves during grain growth. Ann. Bot. N.S. $32: 79-95$. 